\title{
Evaluation of Women's Satisfaction Regarding MCH Services Provided in Health Care Centers with High Maternal and Infant Mortality Rate in Wassit Governorate
}

\author{
Ahmed Thani Sadoon $(\mathrm{BSC})^{1}$ and Basim Hussein Bahir $(\mathrm{PhD})^{2}$
}

\section{Abstract}

Background: As client opinion is useful to improve MCH service delivery, evaluation of client satisfaction should be undertaken periodically.

Objective: To determine the level of satisfaction of pregnant women and mothers regard health care services provided in the $\mathrm{MCH}$ units in Wassit Governorate.

Patients and Methods: A cross-sectional study, with a convenient sample of mothers and pregnant women who were attending to the $\mathrm{MCH}$ clinics. The study was conducted in three sectors with high maternal and infant mortality rate which include 28 health care centers in Wassit Governorate. Data were collected through the period starting on 16 December 2018 and ending on 31 March 2019, using a specially designed questionnaire.

Results: The important inference of this study is the quality of care from the pregnant women and mothers perspective that reflected in client satisfaction. This study has revealed that $(67.5 \%)$ of pregnant women were fairly satisfied, while $67.1 \%$ of mothers were fairly satisfied with health care services provided in $\mathrm{MCH}$ units at different PHC centers in Wassit city.

Conclusion: This study revealed that the majority of pregnant women and mothers were fairly satisfied with health care services provided by the $\mathrm{MCH}$ unit in the Wassit Governorate and the quality of antenatal care and care for children less than 5 years provided at studied $\mathrm{MCH}$ centers need to be improved in all activities.

Keywords:Women's satisfaction, MHC services, Health care, Maternal mortality, Infant mortality.

Corresponding Author: ahmedthani.10@gmail.com

Received: $17^{\text {th }}$ July 2019

Accepted: $7^{\text {th }}$ August 2019

DOI:https://doi.org/10.26505/DJM.18014800717

${ }^{1,2}$ College of Health and Medical Technology -Middle Technical University- Baghdad -Iraq.

\section{Introduction}

Patients' satisfaction is considered as an important indicator when measured quality, of health care services deliveries in both low and middle-income countries and constitutes a significant component for assessing the health care outcome. Studies showed that Patients' satisfied is a good way to develop a relationship with the health care system, 
Evaluation of Women's Satisfaction Regarding MCH Services Provided in Health Care Centers with High

Maternal and Infant Mortality Rate in Wassit Governorate

leading to Improve Patients' compliance, continuity of care and better health outcome at the latest [1].

Despite improvements and developments in the delivery of Mothers and Children $(\mathrm{MCH})$ services, studies have indicated that poor provision of essential $\mathrm{MCH}$ interventions, poor quality, and low coverage, remain a big challenge for most countries [2].

There is a growing interest in measuring clients' satisfaction, through collecting the opinions, and concerns of service users. These opinions have become an important tool for evaluation of health care delivery and health service performance. Client satisfaction is an important indicator of early detection against potential problems in the provision of health services [3].

A secondary aspect is that through a survey, any organization demonstrates its interest in communicating with consumers in finding out their pleasures, displeasure, needs and well-being. Despite measuring the satisfaction of every client is impossible, these clients whose opinions are request and others who observe these activities and process are given a level of importance and recognition [4].

Prenatal care, antenatal care, child health care and childhood vaccination make up the most important package of preventive services that can save and improve women and child health. Families tend to use private medical services when someone is Suffering from health problem, but frequently neglect beneficial of these preventive services that are essential to improve maternal health [5].
Quality of clients' satisfaction and $\mathrm{MCH}$ services is interrelated concepts. Determine the quality of health services represents a true challenge, and the studies have indicated that a positive correlation between clients' satisfaction and $\mathrm{MCH}$ services utilization and providing better health care services is indicated an important concept for the future socioeconomic and well-being of any country [6].

\section{Patients and Methods}

The Wassit is a Governorate about 180 kilometers south of Baghdad Governorate the capital of Iraq and accounts for four percent of the total area of Iraq. According to the census conducted in 2018 by the local and central authorities, the whole population of the Wassit Governorate was 1,360,000 inhabitants.

\section{Design and setting of the study}

A descriptive, cross-sectional study, with a convenient sample of pregnant women and mothers who attended to the $\mathrm{MCH}$ clinic. The study was conducted in sectors with high maternal and infant mortality rates (AL-Kut first sector, AL-Kut second sector, and AlNummania sector) which include 28 health care centers in Wassit Governorate. Data were collected through the period starting on 16 December 2018 and ending on 31 March 2019, using a special designed questionnaire.

Inclusion criteria all pregnant women and mothers of a child under five years of age were included in the study.

\section{Data collection technique}

Data were collected using a special designed questionnaire that was adopted 
Evaluation of Women's Satisfaction Regarding MCH Services Provided in Health Care Centers with High

Maternal and Infant Mortality Rate in Wassit Governorate

from basic health service's package from the Iraqi Ministry of Health [7]. With the addition of a few minor modifications after reviewing previous studies. Content validity was determined for the questionnaire through the use of a panel of eight experts in order to evaluate its contents, clarity, relevance and adequacy to achieve the present study aims.

Data of women's satisfaction with maternal and child care unit were collected from pregnant women and mothers. Data were collected by direct interview by using questionnaires. Each interview lasts 15-20 minutes this includes questions about: demographic data, gestation status and satisfaction and acceptance of pregnant women and mothers.

\section{Statistical analysis}

Was done using the SPSS (version 25) package program was employed in the statistical analysis. Data were presented in simple measures as follows: Frequency and percentage, Mean and SD (standard deviation), and Range (minimum-maximum values).

Assessment score of mothers was determined according to the quartile status where those below second quartile $(<46)$ considered as poor services, on third quartile (46-57) as fair and above third quartile $(\geq 58)$ as good services. There were 23 questions and the answers were scored as follows (3) for always, (2) for sometimes and (1) for no. While assessment scores of pregnant women was determined according to the quartile status where those below second quartile $(<54)$ considered as poor services, on third quartile (54-67) as fair and above third quartile $(\geq 68)$ as good services. There were 27 questions and the answers were scored as follows (3) for always, (2) for sometimes and (1) for no.

Limitations of the study:

1. Some pregnant refused to participate in the study.

2. There is no comprehensive program for the evaluation of $\mathrm{MCH}$ services.

\section{Results}

Distributions of Demographic data and Gestation status for Mothers and Child

General characteristics of the mothers are described in table 1. Three hundred and forty three (343) mothers were involved in this study. Most of the mothers $(31.5 \%)$ were in age group (25-29) years. Over one quarter of them $(27.1 \%)$ were illiterates and $25.4 \%$ had one previous pregnancy. Approximately $84 \%$ of these mothers delivered their children in hospitals and $55.4 \%$ had a regular health visit to the child at the health care center. 
Evaluation of Women's Satisfaction Regarding MCH Services Provided in Health Care Centers with High

Maternal and Infant Mortality Rate in Wassit Governorate

Table (1): Demographic data and Gestation status for Mother and Child

\begin{tabular}{|c|c|c|c|}
\hline & & No & $\%$ \\
\hline \multirow{3}{*}{ Sector } & First Kut Sector & 128 & 37.3 \\
\hline & Second Kut Sector & 161 & 46.9 \\
\hline & Al Numania Sector & 54 & 15.7 \\
\hline \multicolumn{4}{|l|}{ 1-Demographic data } \\
\hline \multirow{6}{*}{ Age of the mother (years) } & $<20$ & 30 & 8.7 \\
\hline & $20-24$ & 87 & 25.4 \\
\hline & $25-29$ & 108 & 31.5 \\
\hline & $30-34$ & 66 & $\overline{19.2}$ \\
\hline & $\geq 35$ & 52 & 15.2 \\
\hline & " Mean \pm SD (Range) & \multicolumn{2}{|c|}{$27.1 \pm 6.14(16-46)$} \\
\hline \multirow{3}{*}{ Social status } & Married & 341 & $\overline{999.4}$ \\
\hline & Divorced & $\overline{22}$ & 0.6 \\
\hline & Widow & 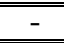 & 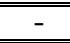 \\
\hline \multirow{6}{*}{ Level of education } & "Illiterate & 93 & 27.1 \\
\hline & Read and write & 65 & $\overline{19}$ \\
\hline & Primary & 89 & 25.9 \\
\hline & Intermediate & 40 & 11.7 \\
\hline & Secondary & 222 & 6.4 \\
\hline & Institute/College & 34 & 9.9 \\
\hline \multicolumn{4}{|l|}{ 2-Gestation status: } \\
\hline \multirow{8}{*}{ 2-1-Number of previous pregnancies } & $\overline{00}$ & 46 & 13.5 \\
\hline & $\overline{11}$ & 87 & 25.4 \\
\hline & 2 & 71 & 20.8 \\
\hline & $\overline{\overline{3}}$ & 61 & 17.8 \\
\hline & 4 & 45 & 13.2 \\
\hline & 5 & 16 & 4.7 \\
\hline & $\geq 6$ & 16 & 4.6 \\
\hline & Mean \pm SD (Range) & \multicolumn{2}{|c|}{$2.3 \pm 1.78(0-13)$} \\
\hline \multirow{2}{*}{ 2-2-Place of last birth } & "Hospital & 287 & 83.7 \\
\hline & Midwives & 56 & 16.3 \\
\hline \multirow{2}{*}{$\begin{array}{l}\text { 2-3- The regularity of child's visits to } \\
\text { health care center }\end{array}$} & Regular & $\overline{190}$ & $\overline{55.4}$ \\
\hline & Irregular & 153 & 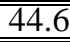 \\
\hline
\end{tabular}

\section{Satisfaction and acceptance of mothers about the health services}

Details of mothers' responses to the questions of satisfaction and acceptance of mothers about the health services are shown in table 2. Most of mothers were satisfied that their baby's weight and height had always measured has constituted $88 \%$, while majority of the mothers have been reported of the lack of health services regarding the measurement of their baby breathing rate 95.9\%, distribution of pills and condoms $95.6 \%$, oral and dental examination $92.1 \%$ and measurement their child temperature $81.6 \%$ respectively. About mother satisfaction on doctors' service, this table shows that about half of mothers $49.9 \%$ not satisfied with their doctor examination and carefulness to check everything. In considering pharmacy services, $48.1 \%$ of mothers reported that sometimes the medications prescribed by the physician are available and adequate. Mothers who neglect their supply with iron and folic acid pills have constituted $91.3 \%$. Regarding the generally satisfied mothers, $46.1 \%$ of 
Evaluation of Women's Satisfaction Regarding MCH Services Provided in Health Care Centers with High

Maternal and Infant Mortality Rate in Wassit Governorate

mothers said sometimes patients receive the best care from the staff working at this practice and about three quarters $72.3 \%$ of studied mothers, answered that they were always had absolute faith and confidence in the doctors, while $70.3 \%$ of mothers were always had full confidence in the medical staff they treat them.

Table (2): Satisfaction and acceptance of mothers about the health services

\begin{tabular}{|c|c|c|c|c|c|c|}
\hline \multirow{2}{*}{ Satisfaction of mothers about the health services } & \multicolumn{2}{|c|}{ Always } & \multicolumn{2}{|c|}{ Sometimes } & \multicolumn{2}{|c|}{ No } \\
\hline & No & $\%$ & No & $\%$ & No & $\%$ \\
\hline \multicolumn{7}{|l|}{ a-Mothers and child related services $\&$ satisfaction } \\
\hline Is the baby's weight and height measured & 302 & 88 & 18 & 5.2 & 23 & 6.7 \\
\hline Measure the baby's breathing rate & 9 & 2.6 & 5 & 1.5 & 329 & 95.9 \\
\hline Measuring the temperature of the child & 47 & 13.7 & 16 & 4.7 & 280 & 81.6 \\
\hline Oral and dental examination & 19 & 5.5 & 8 & 2.3 & 316 & 92.1 \\
\hline $\begin{array}{l}\text { Is your child vaccinated with the vaccine due and } \\
\text { according to the vaccine schedule }\end{array}$ & 332 & 96.8 & 9 & 2.6 & 2 & 0.6 \\
\hline $\begin{array}{l}\text { Advised on family planning ( distribution of pills and } \\
\text { condoms) }\end{array}$ & 10 & 2.9 & 5 & 1.5 & 328 & 95.6 \\
\hline \multicolumn{7}{|l|}{ b-Question list about doctor services } \\
\hline $\begin{array}{l}\text { The doctor is very careful to check everything when } \\
\text { he examining me }\end{array}$ & 120 & 35 & 52 & 15.2 & 171 & 49.9 \\
\hline The doctor is very interested in the patient & 150 & 43.7 & 133 & 38.8 & 60 & 17.5 \\
\hline $\begin{array}{l}\text { I feel I have not been given enough information by } \\
\text { the doctor }\end{array}$ & 194 & 56.6 & 59 & 17.2 & 90 & 26.2 \\
\hline the doctor makes me feel I am wasting his/her time & 43 & 12.5 & 47 & 13.7 & 253 & 73.8 \\
\hline The doctor is very understanding and Collaborator & 166 & 48.4 & 151 & 44 & 26 & 7.6 \\
\hline $\begin{array}{l}\text { In general there is harmony and compatibility } \\
\text { between the work of the Doctor and the health worker } \\
\text { when treating the mother and her child }\end{array}$ & 174 & 50.7 & 111 & 32.4 & 58 & 16.9 \\
\hline \multicolumn{7}{|l|}{ c-Question about pharmacy services } \\
\hline $\begin{array}{l}\text { The pharmacist's instructions about how to take your } \\
\text { medication }\end{array}$ & 253 & 73.8 & 45 & 13.1 & 45 & 13.1 \\
\hline $\begin{array}{l}\text { Medications prescribed by the physician are available } \\
\text { and adequate }\end{array}$ & 96 & 28 & 165 & 48.1 & 82 & 23.9 \\
\hline $\begin{array}{l}\text { It is supplied with iron and folic acid pills and in } \\
\text { sufficient quantity }\end{array}$ & 19 & 5.5 & 11 & 3.2 & 313 & 91.3 \\
\hline \multicolumn{7}{|l|}{ d-Questions regarding access to the health center } \\
\hline $\begin{array}{l}\text { The time it takes since the patient enters the health } \\
\text { center, waiting for admission to the doctor, doing the } \\
\text { tests and taking the prescription is convenient and } \\
\text { appropriate. }\end{array}$ & 181 & 52.8 & 154 & 44.9 & 8 & 2.3 \\
\hline
\end{tabular}


Evaluation of Women's Satisfaction Regarding MCH Services Provided in Health Care Centers with High

Maternal and Infant Mortality Rate in Wassit Governorate

\begin{tabular}{|c|c|c|c|c|c|c|}
\hline You can reach to the center from home or work. & 226 & 65.9 & 58 & 16.9 & 59 & 17.2 \\
\hline \multicolumn{7}{|l|}{ e-Questions about general satisfaction } \\
\hline $\begin{array}{l}\text { Patients receive the best care from the staff working } \\
\text { at this practice }\end{array}$ & 99 & 28.9 & 158 & 46.1 & 86 & 25.1 \\
\hline I have absolute faith and confidence in the doctors & 248 & 72.3 & 69 & 20.1 & 26 & 7.6 \\
\hline $\begin{array}{l}\text { In general, the mother has full confidence in the } \\
\text { medical staff that is treating her. }\end{array}$ & 241 & 70.3 & 88 & 25.7 & 14 & 4.1 \\
\hline $\begin{array}{l}\text { Are you satisfied with the level of services given to } \\
\text { you }\end{array}$ & 90 & 26.2 & 206 & 60.1 & 47 & 13.7 \\
\hline \multicolumn{7}{|l|}{ f-Services-related questions } \\
\hline There are enough seats in the waiting room & 105 & 30.6 & 112 & 32.7 & 126 & 36.7 \\
\hline $\begin{array}{l}\text { The room where mother and child care is provided is } \\
\text { characterized by lighting, heating, comfort and } \\
\text { tranquility. }\end{array}$ & 157 & 45.8 & 129 & 37.6 & 57 & 16.6 \\
\hline
\end{tabular}

services provided, while $31.8 \%, 1.2 \%$ had

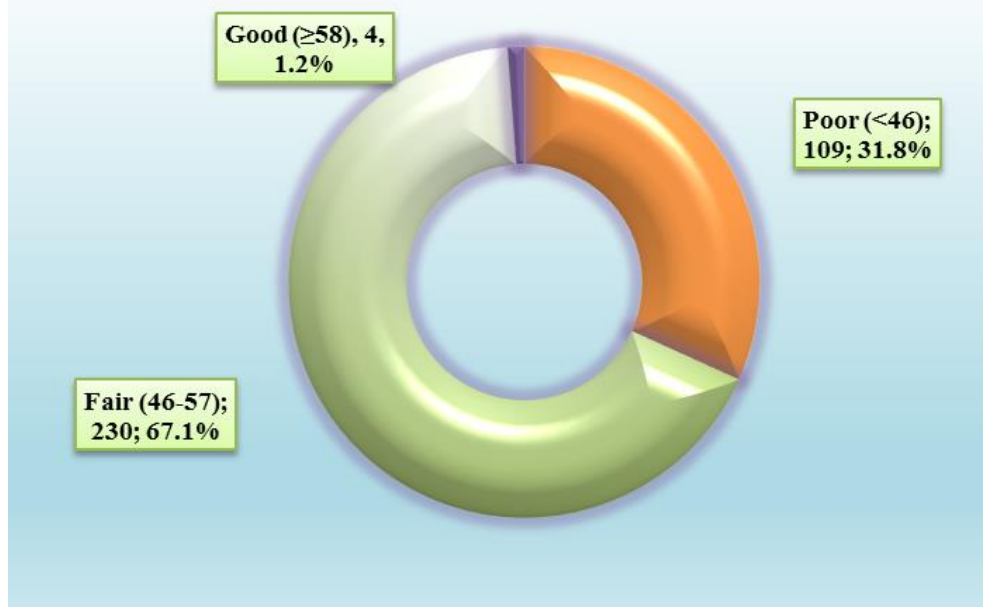

Figure(1): Mothers Overall satisfaction score

Distribution of Demographic data and Gestation status for pregnant women

Table (4) showed that most of the pregnant women $33.7 \%$ were aged between 20 to 24 years. It has been found that the highest percentages of them $48.8 \%$ were married at the age between 15 and 19 years. Among them, $20.5 \%$ were illiterates and $31.9 \%$ have no previous pregnancies. On the other hand,
$88.5 \%$ of mothers delivered in the hospital, ninety-one percent prefer a hospital as a place of birth. Pregnant women who have their first antenatal visit during the second trimester constitute $65.7 \%$ and $68.1 \%$ of them had regular antenatal visits to the health center. Only $17.4 \%$ of pregnant women have four visits to the health center during pregnancy. 
Evaluation of Women's Satisfaction Regarding MCH Services Provided in Health Care Centers with High

Table (3): Demographic data and Gestation status for pregnant women

\begin{tabular}{|c|c|c|c|}
\hline & & No & $\%$ \\
\hline Directorate & $\begin{array}{l}\text { Wassit Health } \\
\text { Directorate }\end{array}$ & 166 & 100 \\
\hline \multicolumn{4}{|l|}{ 1-Demographic data } \\
\hline \multirow{6}{*}{ Age (years) } & $<20 \mathrm{y}$ & 31 & 18.7 \\
\hline & $20-24$ & $\overline{56}$ & 33.7 \\
\hline & $25-29$ & 39 & 23.5 \\
\hline & 30-34 & 23 & 13.9 \\
\hline & $\geq 35 \mathrm{y}$ & 17 & 10.2 \\
\hline & $\begin{array}{l}\text { Mean } \pm \text { SD } \\
\text { (Range) }\end{array}$ & \multicolumn{2}{|c|}{$25.1 \pm 6.09(15-42)$} \\
\hline \multirow{6}{*}{ Age at time of marriage (years) } & $<15 \mathrm{y}$ & 7 & 4.2 \\
\hline & $15-19$ & 81 & 48.8 \\
\hline & $20-24$ & 59 & 35.5 \\
\hline & $25-29$ & 17 & 10.2 \\
\hline & $\geq 30 \mathrm{y}$ & 2 & 1.2 \\
\hline & $\begin{array}{l}\begin{array}{l}\text { Mean } \pm \text { SD } \\
\text { (Range) }\end{array} \\
\end{array}$ & \multicolumn{2}{|c|}{$19.6 \pm 3.56(13-31)$} \\
\hline \multirow{6}{*}{ Level of education } & Illiterate & 34 & 20.5 \\
\hline & $\begin{array}{l}\text { Read and } \\
\text { write }\end{array}$ & 27 & 16.3 \\
\hline & Primary & 43 & 25.9 \\
\hline & Intermediate & 21 & 12.7 \\
\hline & Secondary & 19 & 11.4 \\
\hline & $\begin{array}{l}\text { Institute/Colle } \\
\text { ge }\end{array}$ & 22 & 13.3 \\
\hline \multicolumn{4}{|l|}{ 2-Gestation status: } \\
\hline \multirow{7}{*}{ Number of previous pregnancies } & 0 & 53 & 31.9 \\
\hline & 1 & 45 & 27.1 \\
\hline & 2 & 23 & 13.9 \\
\hline & 3 & 25 & 15.1 \\
\hline & 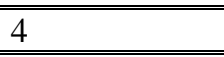 & 10 & 6 \\
\hline & $\geq 5$ & 10 & 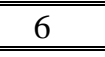 \\
\hline & $\begin{array}{l}\begin{array}{l}\text { Mean } \pm \text { SD } \\
\text { (Range) }\end{array} \\
\end{array}$ & \multicolumn{2}{|c|}{$1.6 \pm 1.75(0-10)$} \\
\hline \multirow{2}{*}{ Place of last birth } & Hospital & 100 & 88.5 \\
\hline & Midwives & 13 & 11.5 \\
\hline \multirow{2}{*}{ Where do you prefer the place of birth in current pregnancy } & Hospital & 151 & 91 \\
\hline & Midwives & 15 & 9 \\
\hline \multirow{3}{*}{ First antenatal visit } & $\begin{array}{l}\text { First trimester } \\
\end{array}$ & 54 & 32.5 \\
\hline & $\begin{array}{l}\text { Second } \\
\text { trimester } \\
\end{array}$ & 109 & 65.7 \\
\hline & $\begin{array}{l}\text { Third } \\
\text { trimester }\end{array}$ & 3 & 1.8 \\
\hline Did your commitment to visits during the current period of & Regular & 113 & 68.1 \\
\hline
\end{tabular}


Evaluation of Women's Satisfaction Regarding MCH Services Provided in Health Care Centers with High

Maternal and Infant Mortality Rate in Wassit Governorate

\begin{tabular}{|c|c|c|c|}
\hline pregnancy was: & Irregular & 53 & 31.9 \\
\hline \multirow{4}{*}{ Number of visits } & $\overline{11}$ & $\overline{557}$ & 34.3 \\
\hline & 2 & 53 & 31.9 \\
\hline & 3 & 27 & 16.3 \\
\hline & $\geq 4$ & 29 & 17.4 \\
\hline
\end{tabular}

Satisfaction \& acceptance of Pregnant mothers about the health services

Details of pregnant women's responses to the questions satisfaction and acceptance of mothers about the health services are shown in table 5. Pregnant women who did not receive advice about danger signs constitute $80.7 \%$. About half of them did not receive folic-acid and ferrofol. However, Most of the pregnant women in the study sample reported, in high proportions, that they always take the tetanus vaccine.89.8\%, always measured for blood pressure $86.7 \%$, and always checked for urine $75.3 \%$. With regard to the satisfaction of pregnant women on the services provided by the doctor, more than half $58.4 \%$ were not satisfied with doctor examination and carefulness to check everything. In considering pharmacy services, $36.7 \%$ of pregnant reported sometimes medications prescribed by the physician are available and adequate. Pregnant women who neglect their supply with iron and folic acid pills constitute $51.2 \%$. Regarding the generally satisfied pregnant women, $48.2 \%$ of pregnant women reported sometimes patients receive the best care from the staff working at this field. In addition, $65.1 \%$ of pregnant women in the study sample always had absolute faith and confidence in doctors, while $72.3 \%$ of pregnant women were always having full confidence in the medical staff they treat them.

Table (4): Demographic data and Gestation status for pregnant women

\begin{tabular}{|c|c|c|c|c|c|c|}
\hline \multirow{2}{*}{$\begin{array}{l}\text { Satisfaction of Pregnant mothers about the health } \\
\text { services }\end{array}$} & \multicolumn{2}{|c|}{ Always } & \multicolumn{2}{|c|}{ Sometimes } & \multicolumn{2}{|c|}{ No } \\
\hline & No & $\%$ & No & $\%$ & No & $\%$ \\
\hline \multicolumn{7}{|l|}{ a-Women's related services \& satisfaction } \\
\hline Advised about danger signs & 12 & 7.2 & 20 & 12 & 134 & 80.7 \\
\hline Received tablet of folic-acid and ferrofol & 65 & 39.2 & 17 & 10.2 & 84 & 50.6 \\
\hline does the pregnancy weight and height is measured & 140 & 84.3 & 17 & 10.2 & 9 & 5.4 \\
\hline $\begin{array}{l}\text { Is the pregnant woman vaccinated with tetanus toxoid } \\
\text { vaccine }\end{array}$ & 149 & 89.8 & 4 & 2.4 & 13 & 7.8 \\
\hline blood pressure measurement & 144 & 86.7 & 2 & 1.2 & 20 & 12 \\
\hline blood glucose measurement & 44 & 26.5 & 5 & 3 & 117 & 70.5 \\
\hline Urine analysis & 125 & 75.3 & 8 & 4.8 & 33 & 19.9 \\
\hline $\begin{array}{l}\text { Oral and dental examination in (first, second and third } \\
\text { trimester) of pregnancy }\end{array}$ & 53 & 31.9 & 17 & 10.2 & 96 & 57.8 \\
\hline b-Question list about doctor services & & & & & & \\
\hline
\end{tabular}


Evaluation of Women's Satisfaction Regarding MCH Services Provided in Health Care Centers with High

Maternal and Infant Mortality Rate in Wassit Governorate

Ahmed Thani Sadoon

\begin{tabular}{|c|c|c|c|c|c|c|}
\hline $\begin{array}{l}\text { The doctor is very careful to check everything when } \\
\text { examining me }\end{array}$ & 41 & 24.7 & 28 & 16.9 & 97 & 58.4 \\
\hline The doctor is very interested in the patient & 71 & 42.8 & 67 & 40.4 & 28 & 16.9 \\
\hline $\begin{array}{l}\text { I feel I have not been given enough information by the } \\
\text { doctor }\end{array}$ & 91 & 54.8 & 31 & 18.7 & 44 & 26.5 \\
\hline the doctor makes me feel I am wasting his/her time & 19 & 11.4 & 33 & 19.9 & 114 & 68.7 \\
\hline The doctor is very understanding and Collaborator & 72 & 43.4 & 77 & 46.4 & 17 & 10.2 \\
\hline $\begin{array}{l}\text { In general there is harmony and compatibility between } \\
\text { the work of the doctor and the health worker when } \\
\text { treating the mother and her child }\end{array}$ & 94 & 56.6 & 53 & 31.9 & 19 & 11.4 \\
\hline \multicolumn{7}{|l|}{ c-Question about pharmacy services } \\
\hline $\begin{array}{l}\text { The pharmacist's instructions about how to take your } \\
\text { medication }\end{array}$ & 115 & 69.3 & 20 & 12 & 31 & 18.7 \\
\hline $\begin{array}{l}\text { Medications prescribed by the physician are available } \\
\text { and adequate }\end{array}$ & 60 & 36.1 & 61 & 36.7 & 45 & 27.1 \\
\hline $\begin{array}{l}\text { It is supplied with iron and folic acid pills and in } \\
\text { sufficient quantity }\end{array}$ & 59 & 35.5 & 22 & 13.3 & 85 & 51.2 \\
\hline \multicolumn{7}{|l|}{ d-Question about laboratory services } \\
\hline there is a clean waiting area in laboratory & 95 & 57.2 & 52 & 31.3 & 19 & 11.4 \\
\hline $\begin{array}{l}\text { Patients are satisfied with laboratory personnel } \\
\text { welcoming approach }\end{array}$ & 130 & 78.3 & 30 & 18.1 & 6 & 3.6 \\
\hline \multicolumn{7}{|l|}{ e-Questions regarding access to the health center } \\
\hline $\begin{array}{l}\text { The time it takes since the patient enters the health } \\
\text { center, waiting for admission to the doctor, doing the } \\
\text { tests and taking the prescription is convenient and } \\
\text { appropriate. }\end{array}$ & 66 & 39.8 & 87 & 52.4 & 13 & 7.8 \\
\hline You can reach to the center from home or work. & 109 & 65.7 & 27 & 16.3 & 30 & 18.1 \\
\hline \multicolumn{7}{|l|}{ f- Questions about general satisfaction } \\
\hline $\begin{array}{l}\text { Patients receive the best care from the staff working at } \\
\text { this practice }\end{array}$ & 42 & 25.3 & 80 & 48.2 & 44 & 26.5 \\
\hline I have absolute faith and confidence in the doctors & 108 & 65.1 & 38 & 22.9 & 20 & 12 \\
\hline $\begin{array}{l}\text { In general, the mother has full confidence in the } \\
\text { medical staff that is treating her and satisfied with the } \\
\text { level of the service. }\end{array}$ & 120 & 72.3 & 36 & 21.7 & 10 & 6.0 \\
\hline $\begin{array}{l}\text { Are you satisfied with the level of services given to } \\
\text { you }\end{array}$ & 56 & 33.7 & 88 & 53 & 22 & 13.3 \\
\hline \multicolumn{7}{|l|}{ g-Services-related questions } \\
\hline There are enough seats in the waiting room & 56 & 33.7 & 57 & 34.3 & 53 & 31.9 \\
\hline $\begin{array}{l}\text { The room where mother and child care is provided is } \\
\text { characterized by lighting, heating, comfort and } \\
\text { tranquility. }\end{array}$ & 77 & 46.4 & 59 & 35.5 & 30 & 18.1 \\
\hline
\end{tabular}


This figure showed that $67.5 \%$ of pregnant women had fair level of satisfaction with the health care services provided, while $14.5 \%$ had good level of satisfaction.

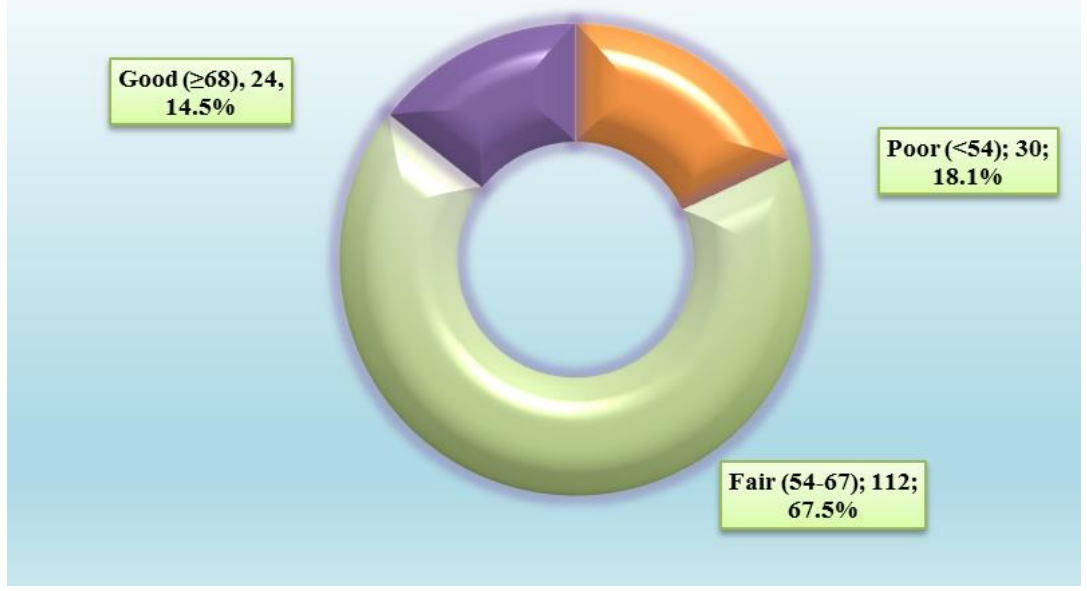

Figure(2): Pregnant women Overall satisfaction score

\section{Discussion}

The important inference of this study is the quality of care from the pregnant women perspective that reflected in client satisfaction. This study has revealed fairly results $(67.5 \%)$, regarding satisfaction of pregnant women attending $\mathrm{MCH}$ at different PHC centers in Wassit city.

These results disagreed with those observed in previous studies conducted in Baghdad city [3], Erbil city [8] and Saudi Arabia [1], which showed that the pregnant women were satisfied with health care services provided by the $\mathrm{MCH}$ unit. A possible explanation might be shortage in the females medical staff, absence of gynecologist, no availability of ultra sound examination, poor staff attitude, long waiting time, poor attention to pregnant women, absence home visits, weak supervision, All of these reasons mentioned lead pregnant women to use private medical services when they have some pregnancy complications.
As regarded demographic data and gestation status for pregnant women the current study found that the $33.7 \%$ were in the age group (20-24) years, and $25.9 \%$ of them were in primary level of education. These results agreed with those observed in another Egyptian study [9], this showed that $36 \%$ of pregnant women in the age group (20-25) and $43.3 \%$ have a primary as a level of education.

About pregnant women's services \& satisfaction the study found that $80.7 \%$ of pregnant women were not satisfied regarding advice about danger signs. This finding was different from what was found in a Nigerian study, where $84.9 \%$ of pregnant women reported to be satisfied with the advice provided on danger signs of pregnancy [10]. This may be due to the small number of health care providers in health centers and the weakness of health education for 
pregnant women to avoid those risks of pregnancy.

With regard to services provided by doctors, the study indicates that $58.4 \%$ of pregnant women were dissatisfied, particularly with regard to the doctor's care to check them out well. These results differ from a study conducted in Islamabad [11], which showed that $97.1 \%$ of pregnant women satisfied were the doctor is checkup. There are two likely reasons for the differences, the first is shortage of medical staff in most of PHCs and the second reason is the lack of tools and equipment.

Regarding to pharmacy services, the study indicates that $36.1 \%$ of pregnant women were satisfied that the, medications prescribed by the physician are available and adequate. These results consistent to those observed in earlier Iraqi study, in Baghdad [12], which found that $45.5 \%$ of pregnant women were satisfied that the medications prescribed by the physician are available. But it is different from what another Iraqi study found in Erbil. where the percentage was high $91.3 \%$ [8]. A possible explanation, that the essential drug for pregnant women was not available in most PHCs.

The study also indicated that 51.2 per cent of pregnant women were dissatisfied with iron and folic acid pills supplied in sufficient quantities. This result is in agreement with the another Nepalese study [13].

The current study demonstrated that $67.1 \%$ of mothers were fairly satisfied and $31.8 \%$ were poor satisfied with health care services provided for children. These results are agreed with other studies in Iraq, Basra city [14], and in India [15], Where it was found that $76.75 \%, 54.31 \%$ of mothers were fairly satisfied respectively. However, the results of the current study were disagreed with a Nigerian study [16], and another Egyptian study [17] respectively. This difference might be due to substandard health care services, long waiting time, poor staff attitude, absence of doctors or some centers had one doctor and most of the children were treated by paramedical staff in PHC, these factors have an effect on mothers' satisfaction, about child health services.

\section{Conclusions}

This study revealed that the majority of women (pregnant and mothers) were fairly satisfied with health care services provided by the $\mathrm{MCH}$ unit in the health care centers with high maternal and infant mortality rates in the Wassit governorate. The quality of antenatal care, and care for children less than 5 years provided at studied $\mathrm{MCH}$ centers need urgent action to be improved in all activities.

\section{References}

[1]Mohamed EY, Sami W, Alotaibi A, Alfarag A, Almutairi A, Alanzi F. Patients' satisfaction with primary health care Centers' Services, Majmaah, kingdom of Saudi of Saudi Arabia. Int J Health Sci (Qassim). 2015;9(2):163-70.

[2]Friberg IK, Kinney M V, Lawn JE, Kerber KJ, Odubanjo MO, Bergh A-M, et al. SubSaharan Africa's mothers, newborns, and children: how many lives could be saved 
Evaluation of Women's Satisfaction Regarding MCH Services Provided in Health Care Centers with High

Maternal and Infant Mortality Rate in Wassit Governorate

with targeted health interventions? PLoS Med. 2010;7(6):1-8.

[3]YassenTaha T. Evaluation of Clients' Satisfaction towards Primary Health Care Centers Services at Baghdad City. Nurs Natl Iraqi specility. 2017;30(2):54-62.

[4]Pizam A, Shapoval V, Ellis T. Customer satisfaction and its measurement in hospitality enterprises: a revisit and update. Int J Contemp Hosp Manag. 2016;28(1):235 .

[5]Watterson JL, Walsh J, Madeka I. Using mHealth to improve usage of antenatal care, postnatal care, and immunization: a systematic review of the literature. Biomed Res Int. 2015;22(12):7-8.

[6]Taghavi S, Ghojazadeh M, AzamiAghdash S, Alikhah $\mathrm{H}$, Bakhtiarzadeh K, Azami A, et al. Assessment of mothers' satisfaction with the care of maternal care in Specialized Educational-Medical Centers in obstetrics and gynecological disease in Northwest, Iran. J Anal Res Clin Med. 2015;3(2):77-86.

[7] MOH, Iraq M. A Basic Health Services package for Iraq With the Technical Support from World Health Organization [Internet]. 2009 [cited 2019 Mar 31]. Available from: http://applications.emro.who.int/dsaf/libcat/e mropd_2009_109.pdf

[8]Sabir JM. Women's satisfaction about $\mathrm{MCH}$ care services provided to pregnants attend antenatal care units in Erbil city. Zanco J Med Sci. 2010;14(1):16-21. [9]Allah E, Elsayed Mohamed Elsabagh E, El Awady S. Mother's Satisfaction with the Quality Care Of Maternal \& Child Health
Services At Maternal and Child Health Centers in Zagazig City, Sharkia Governorate, Egypt. Life Sci J. 2012 Jan 1;9(3):1438-48.

[10]Nwaeze IL, Enabor OO, Oluwasola TAO, Aimakhu CO. Perception and satisfaction with quality of antenatal care services among pregnant women at the university college hospital, Ibadan, Nigeria. Ann Ibadan Postgrad Med. 2013;11(1):22-8. [11]Savul S, Naeem Z, Naseem S. Satisfaction of Female Patients with Health Care Services at the Peri-urban Community Health Centre in Islamabad. Cureus. 2018;10(8):2-10.

[12]Khalifa MF, Sa'adoun NY. Determination of Quality Assurance for Maternal and Child Health Services in Baghdad City. Nurs Natl Iraqi specility. 2010;8(3):1-10.

[13]Acharya SK, Sharma SK, Dulal BP, Aryal KK. Quality of care and client satisfaction with maternal health services in Nepal. Further analysis of the 2015 Nepal Health Facility Survey. Ann Med Health Sci Res. 2018;6(1):11-40.

[14]Dhahi ZK, Issa SS, Hameed LA. A study on pregnant women's satisfaction with primary health care services in Basra. Int $\mathbf{J}$ Res Humanit Arts Lit. 2015;3:7-19.

[15]Das P, Basu M, Tikadar T, Biswas GC, Mridha P, Pal R. Client satisfaction on maternal and child health services in rural Bengal. Indian J community Med Off Publ Indian Assoc Prev Soc Med. 2010;35(4):452-78. 
[16]Odetola TD, Fakorede EO. Assessment of Perinatal Care Satisfaction Amongst Mothers Attending Postnatal Care in Ibadan, Nigeria. Glob Heal. 2018;84(1):36-46.

[17]Abo elghite E. Mothers' Satisfaction Regarding Services Provided at Maternal and Child Health Centers in Tanta City, Egypt. J Community Health Nurs. 2013 Mar 25;11(22):295-310. 